University of Montana

ScholarWorks at University of Montana

\title{
Volatile Chemicals from Leaf Litter are Associated with Invasiveness of a Neotropical Weed in Asia
}

Inderjit

Heather Evans

Christoph Crocoll

Devika Bajpai

Rajwant Kaur

See next page for additional authors

Follow this and additional works at: https://scholarworks.umt.edu/biosci_pubs

Part of the Biology Commons

Let us know how access to this document benefits you.

\section{Recommended Citation}

Inderjit; Evans, Heather; Crocoll, Christoph; Bajpai, Devika; Kaur, Rajwant; Feng, Yu-Long; Silva, Carlos; Carreón, Jacinto Treviño; Valiente-Banuet, Alfonso; Gershenzon, Jonathan; and Callaway, Ragan M., "Volatile Chemicals from Leaf Litter are Associated with Invasiveness of a Neotropical Weed in Asia" (2011). Biological Sciences Faculty Publications. 257.

https://scholarworks.umt.edu/biosci_pubs/257

This Article is brought to you for free and open access by the Biological Sciences at ScholarWorks at University of Montana. It has been accepted for inclusion in Biological Sciences Faculty Publications by an authorized administrator of ScholarWorks at University of Montana. For more information, please contact scholarworks@mso.umt.edu. 


\section{Authors}

Inderjit, Heather Evans, Christoph Crocoll, Devika Bajpai, Rajwant Kaur, Yu-Long Feng, Carlos Silva, Jacinto Treviño Carreón, Alfonso Valiente-Banuet, Jonathan Gershenzon, and Ragan M. Callaway 


\title{
Volatile chemicals from leaf litter are associated with invasiveness of a Neotropical weed in Asia
}

\author{
Inderjit, ${ }^{1,8}$ Heather Evans, ${ }^{2}$ Christoph Crocoll,${ }^{3}$ Devika Bajpai, ${ }^{1}$ Rajwant Kaur, ${ }^{1}$ Yu-Long Feng, ${ }^{4}$ \\ Carlos Silva, ${ }^{5} \mathrm{~J}_{\text {acinto Treviño Carreón, }}{ }^{6}$ Alfonso Valiente-Banuet, ${ }^{5,7}$ Jonathan Gershenzon, ${ }^{3}$ \\ and Ragan M. Callaway ${ }^{2}$ \\ ${ }^{1}$ Department of Environmental Biology, Centre for Environmental Management of Degraded Ecosystems (CEMDE), \\ University of Delhi, Delhi 110007 India \\ ${ }^{2}$ Division of Biological Sciences, University of Montana, Missoula, Montana 59812 USA \\ ${ }^{3}$ Max-Planck-Institute for Chemical Ecology, Department of Biochemistry, Hans-Knöll-Strasse 8, Jena 07745 Germany \\ ${ }^{4}$ Xishuangbanna Tropical Botanical Garden, Chinese Academy of Sciences, Kunming 650223, Yunnan Province, China \\ ${ }^{5}$ Instituto de Ecología, Universidad Nacional Autônoma de Mexico, Departamento de Ecología de la Biodiversidad, \\ Apartado Postal 70-275, C.P. 04510, México, D.F. México, Mexico \\ ${ }^{6}$ Universidad Autónoma de Tamaulipas, Unidad Académica Multidisciplinaria Agronomía y Ciescias, \\ Centro Universitario Adolfo López Mateos, México C.P. 87149 Mexico \\ ${ }^{7}$ Centro de Ciencias de la Complejidad, Universidad Nacional Autónoma de México, Ciudad Universitaria, \\ México, 04510 D.F. México, Mexico
}

\begin{abstract}
Some invasive plant species appear to strongly suppress neighbors in their nonnative ranges but much less so in their native range. We found that in the field in its native range in Mexico, the presence of Ageratina adenophora, an aggressive Neotropical invader, was correlated with higher plant species richness than found in surrounding plant communities where this species was absent, suggesting facilitation. However, in two nonnative ranges, China and India, A. adenophora canopies were correlated with much lower species richness than the surrounding communities, suggesting inhibition. Volatile organic compound (VOC) signals may contribute to this striking biogeographical difference and the invasive success of A. adenophora. In controlled experiments volatiles from $A$. adenophora litter caused higher mortality of species native to India and China, but not of species native to Mexico. The effects of $A$. adenophora VOCs on seedling germination and growth did not differ between species from the native range and species from the nonnative ranges of the invader. Litter from $A$. adenophora plants from nonnative populations also produced VOCs that differed quantitatively in the concentrations of some chemicals than litter from native populations, but there were no chemicals unique to one region. Biogeographic differences in the concentrations of some volatile compounds between ranges suggest that $A$. adenophora may be experiencing selection on biochemical composition in its nonnative ranges.
\end{abstract}

Key words: Ageratina adenophora; allelopathy; Bambusa arundinacea; Bidens biternata; biogeography; China, India, and Mexico field sites; litter; native species richness; novel-weapons hypothesis; plant invasion; volatile organic chemicals.

\section{INTRODUCTION}

Why some plant species are able to attain near monocultural dominance in communities where they are exotic but not where they are native remains poorly understood (Callaway and Maron 2006). But this biogeographic shift in dominance is the essence of exotic "invasion" and in the absence of disturbance, strong competitive interactions are likely to play an important role in establishing the dominance of invaders (Levine et al. 2003, Vilà and Weiner 2004, Maron and Marler 2008, Munshaw and Lortie 2010). Release from specialist herbivores or pathogens may allow plants to be more competitive in nonnative ranges (Keane and Crawley

Manuscript received 25 February 2010; revised 1 July 2010; accepted 22 July 2011. Corresponding Editor: L. Gough.

${ }^{8}$ E-mail: inderjit@cemde.du.ac.in
2002). Successful invaders may possess competitive advantages because they come from a more competitive species pool or happen to possess inherent traits that give them an advantage relative to their new neighbors. One explicit hypothesis for why some species become more competitively dominant in their new ranges is the "novel-weapons hypothesis" (NWH), which poses that some invaders possess allelopathic, anti-herbivore, or antimicrobial chemicals to which native organisms have not adapted, and that these novel compounds provide invaders with direct or indirect competitive advantages (Callaway and Aschehoug 2000, Callaway and Ridenour 2004). Evidence for the NWH comes from experiments in which chemicals produced by invaders were applied to species from invaded and native ranges (Callaway et al. 2008, He et al. 2009), studies comparing allelopathic and defense interactions among invaders and native plants 
(Wikström et al. 2006, Jogesh et al. 2008, Ens et al. 2009a, b, Jarchow and Cook 2009), and literature-based comparisons of the novelty of chemicals produced by invasive species relative to chemicals identified in the native flora (Cappuccino and Arnason 2006).

Early studies of allelopathy focused on volatile organic compounds (VOCs) (Muller et al. 1964, Muller 1965), but interest in VOCs as agents of allelopathy faded after their ecological importance in the field was challenged by experiments showing that herbivores caused the patterns attributed to VOCs (Bartholomew 1970). Recently, VOCs have gained attention in other ecological roles as factors in communication among plants (Karban 2007, Karban and Shiojiri 2009), signals to the predators of herbivore enemies (Kessler and Baldwin 2002), and in self-nonself recognition (Eom et al. 2006). And they have reemerged as potential factors in allelopathic interactions as well (Barney et al. 2005, Eom et al. 2006, Karban 2007).

A plant species that may employ VOCs in allelopathy is Ageratina adenophora (Sprengel) R. M. King and H. Robinson [syn. Eupatorium adenophorum, Asteraceae], a species producing a large number of volatiles with broad biocidal properties (Palá-Paúl et al. 2002). Ageratina adenophora is a shrub native to central Mexico but invasive in subtropical climates throughout the world including Africa, India, the Philippines, Europe, China, and Australia. Ageratina adenophora can establish virtual monocultures where diverse native communities once flourished (Wang and Wang 2006) and appears to be expanding its range in the areas of our study sites in India and China (Zhu et al. 2007). In addition to bioactivity of its VOCs, there is some evidence for $A$. adenophora allelopathy based on tissue extracts and field applications of activated carbon (Song et al. 2000, Zhang et al. 2008). These results plus the powerful and unusual smell of its litter make A. adenophora an interesting candidate for comparing the biological effects of VOCs on competitors from both native and invasive ranges to gain insight into whether allelopathy might play a role in its invasive abilities.

\section{Methods}

\section{Effect of Ageratina adenophora in the field}

There were two field sites in the native range, one in northeast Mexico in the Sierra Madre Oriental near Balcón de Moctezuma (1400 m above sea level; 2336' $\mathrm{N}, 99^{\circ} 13^{\prime} \mathrm{W}$ ) in the state of Tamaulipas, and the other in central Mexico in the state of Querétaro (1740 m a.s.l.; $\left.19^{\circ} 52^{\prime} \mathrm{N}, 100^{\circ} 54^{\prime} \mathrm{W}\right)$. In India, we sampled two sites in Mussoorie $\left(30^{\circ} 28.750^{\prime} \mathrm{N}, 78^{\circ} 03.216^{\prime} \mathrm{E} ; 1663 \mathrm{~m}\right.$ elevation, and $30^{\circ} 28.272^{\prime} \mathrm{N}, 78^{\circ} 03.463^{\prime} \mathrm{E} ; 1866 \mathrm{~m}$, respectively). In China, one site was located at Xujiaba (2430 $\mathrm{m}$ a.s.l.; $24^{\circ} 32^{\prime} \mathrm{N}, 101^{\circ} 1^{\prime} \mathrm{E}$ ) and a second at Taizhong (1420 m a.s.1.; $\left.24^{\circ} 27^{\prime} \mathrm{N}, 100^{\circ} 54^{\prime} \mathrm{E}\right)$. Both sites were in Jingdong County, Yunnan Province, and were $15 \mathrm{~km}$ from each other. At each site in India we randomly placed 20,1×1 m quadrats in large patches of Ageratina adenophora and 20 quadrats in random locations without $A$. adenophora, but near to and surrounding the patches in areas with similar soil type, soil moisture, and topography. In India we counted the number of different species in each quadrat. At each site in Mexico and in China we randomly located 20 shrubs and then randomly located $1 \times 1 \mathrm{~m}$ quadrat under each canopy. Each quadrat under $A$. adenophora canopies was paired with a quadrat in the open. In Mexico and China the cover of each species was estimated in each quadrat in percent cover classes of $1 \%, 2 \%$, and then in $5 \%$ increments from $5 \%$ through $100 \%$ (e.g., $10 \%, 15 \%$, $20 \%$ and so on).

\section{VOC bioassay}

We first tested the effect of VOCs emitted from $A$. adenophora leaf litter on the germination of Bidens biternata and Bambusa arundinacea seedlings at the University of Delhi (Delhi, India). Bambusa arundinacea is native to India and widely distributed (Mangla et al. 2008). Bidens biternata is distributed and naturalized throughout India (Dakshini and Singh 1984). Eight seeds of either B. biternata or B. arundinacea were placed on Whatman filter paper number 1 in each of three 7.5$8.0 \mathrm{~cm}$ diameter glass petri dishes. To maintain uniform moisture, a thin layer of cotton soaked in $10 \mathrm{~mL}$ distilled water was placed below the filter paper. Three petri dishes were then placed in glass chambers (interior diameter 190, height $100 \mathrm{~mm}$ ) at the University of Delhi, with either $20 \mathrm{~g}$ of $A$. adenophora leaf litter, collected as it fell naturally in the field at our Indian field sites and then air-dried, or empty chambers as controls. Chambers were then covered with glass lids. Twenty grams of A. adenophora litter approximated realistic depths of litter observed in the field. For each species and treatment combination there were five glass chambers, thus five replicates. The chambers were incubated at 28 $32^{\circ} \mathrm{C}$ and a $12 \mathrm{~h}: 12 \mathrm{~h}$ light: dark cycle. Seed germination was counted daily and root and shoot lengths were measured after 7 days (B. biternata) or 8 days $(B$. arundinacea). Mean root or shoot lengths were compared with $t$ tests.

\section{Biogeographic comparisons}

Ecologically realistic concentrations of VOCs are very difficult to determine, thus comparing allelopathic effects on species from native and nonnative ranges of invaders adds to the argument for the potential ecological relevance of the interaction as well as yielding evidence for whether or not allelopathy might contribute to invasive success. We collected seeds in the field in communities with $A$. adenophora in Mexico, China, and India. We planted these seeds in $200-\mathrm{cm}^{3}$ "rocket pots" containing $5 \mathrm{~mL}$ of soil and $25 \mathrm{~mL}$ of silica sand. Pots were then placed in $115-\mathrm{L}(84 \times 40 \times 35 \mathrm{~cm})$ transparent plastic bins that contained either $1.5 \mathrm{~L}$ of $A$. adenophora litter collected from Indian populations, or a $1.5-\mathrm{L}$ mixture of field-collected litter from species that do not occur in any of the three ranges, Quercus macrocarpa, 
Acer platanoides, and Populus tremuloides, collected on The University of Montana campus (Missoula, Montana, USA). We used litter from these other species as a control because we did not know what general effects decaying litter might have on $\mathrm{CO}_{2}$ concentrations or concentrations of other volatile substances; thus we were attempting to discriminate between the effects of chemicals emitted from $A$. adenophora litter and the potential effects of other gases that might be emitted from litter in general. None of these three species is known to exert allelopathic effects on other species, nor do we know of measurements of VOCs from these species.

We initially used seeds of 16 species from Mexico, nine species from China, and eight species from India, but germination was high enough to test mortality rates for only five, seven, and seven species, respectively. For each of the 33 species, we planted 30 rocket pots with five seeds each for a total of 990 pots. Three pots of each species were placed in each of 10 bins; five bins contained $A$. adenophora litter while the other five bins contained the Montana litter, as described above. Litter was air-dried for two days and then placed in the bottom of the bins; rocket pots were placed in racks that suspended the rocket pots above the litter without touching. Bins were covered with lids leaving $120 \mathrm{~cm}^{2}$ of each cover open, allowing circulation but ensuring that air within the bins was affected by VOCs; this was attested to by the exceptionally strong smell within the bins and throughout the greenhouse. During the experiment germination was counted as plants emerged but new germinants were thinned so that the survival and final mass of the first germinant was measured in each rocket pot. These seedlings were grown in a greenhouse from 23 January 2008 to 21 March 2008 with ambient light supplemented by metal halide bulbs, keeping photosynthetically active radiation (PAR) during the day above $1200 \mu \mathrm{mol} \cdot \mathrm{m}^{-2} \cdot \mathrm{s}^{-1}$ with a day length of 13 hours. We watered plants every two to three days. After 59 days the final total dry biomass of all individuals, dried at $60^{\circ} \mathrm{C}$ for three days, was measured and mortality was recorded. We analyzed the biomass of individual plants and the mean germination percentage within pots with ANOVAs using region and site as fixed variables, bin as a block, and species as nested random variables within a site. We analyzed mortality by calculating the mean mortality for each species in each treatment across all bins, and then using a one-way ANOVA to compare the means of all species from both nonnative ranges to the means of all species from the native range.

\section{Identification and quantification of volatiles}

We grew $A$. adenophora from seeds of nine separate populations collected in each of three different countries, Mexico, China, and India. Plants were grown side by side in a greenhouse at the Max Planck Institute for Chemical Ecology (Jena, Germany) with additional illumination by sodium lamps. Temperature was maintained at $20-22^{\circ} \mathrm{C}$ during a $16-\mathrm{h}$ light period and at $18-$ $20^{\circ} \mathrm{C}$ during the night; relative humidity was $30-55 \%$. Plants were potted in commercial soil (Tonsubstrat; Klasmann, Geeste/Groß-Hesepe, Germany) and watered every day with tap water. Five months after germination leaves of plants from three populations of the three different origins were collected and dried for 10 $\mathrm{d}$ at room temperature $\left(\sim 25^{\circ} \mathrm{C}\right)$. Dried leaves were homogenized using metal beads with agitation by a paint shaker two times for three minutes each. To collect VOCs from homogenized A. adenophora leaves, we applied a closed-loop stripping method for headspace analysis. We placed $200 \mathrm{mg}$ of homogenized leaves in a 1-L desiccator and VOCs were collected for $2 \mathrm{~h}$ by recirculating desiccator air through a charcoal trap with a pump. VOCs were eluted from the trap with $60 \mu \mathrm{L}$ of ethyl acetate containing $20 \mathrm{ng} / \mu \mathrm{L}$ nonyl acetate as an internal standard (IS).

Plant material from the same harvest was also used for direct solvent extraction of potential VOCs. Here $200 \mathrm{mg}$ homogenized leaves were extracted with $1 \mathrm{~mL}$ of ethyl acetate containing $20 \mathrm{ng} / \mu \mathrm{L}$ IS for $24 \mathrm{~h}$ at room temperature under continuous rotation. Solvent extracts were purified and dried over $\mathrm{Na}_{2} \mathrm{SO}_{4}$. All extractions were performed as four replicates on three populations from each of the three regions. Products of volatile collection and solvent extractions were identified by gas chromatography (Agilent Hewlett-Packard 6890; Agilent Technologies, Santa Clara, California, USA) coupled to a mass selective detector (MS) (Agilent Hewlett-Packard 5973) or a flame ionization detector (FID). For analyses, $2 \mu \mathrm{L}$ of ethyl acetate extracts were injected at $230^{\circ} \mathrm{C}$. Compounds were separated on a DB5-MS column (30 m $\times 0.25 \mathrm{~mm} \times 0.25 \mu \mathrm{m} ; \mathrm{J} \& \mathrm{~W}$ Scientific, Santa Clara, California, USA) with temperature programmed at $40^{\circ} \mathrm{C}$ for 2-min hold rising to $175^{\circ} \mathrm{C}$ at the rate of $3^{\circ} \mathrm{C} / \mathrm{min}$, and to $250^{\circ} \mathrm{C}$ at the rate of $90^{\circ} \mathrm{C} / \mathrm{min}$ with a 3-min final hold. The flow rate of carrier gas for GC-MS (helium) and GC-FID (hydrogen) was 1 and $2 \mathrm{~mL} / \mathrm{min}$, respectively. All terpene products were identified by using Agilent Technologies software (Santa Clara, California, USA) with the Wiley 275.L and NIST 98.1 mass spectra libraries, as well as by comparison of mass spectra and retention times with those of authenticated standards where available.

\section{RESUlTS}

Ageratina adenophora canopies and understory communities in the field

For the sites tested separately in its native range in Mexico, Ageratina adenophora canopies had no significant relationship with quadrat-based species richness (Fig. 1), but across both sites combined, with site as a factor in the analysis, $A$. adenophora canopies were significantly correlated with higher species richness than surrounding vegetation, suggesting a facilitative effect $\left(\right.$ site $\times$ treatment ANOVA; $F_{\text {trt }}=5.45 ; \mathrm{df}=1,76 ; P=$ 
0.022). In contrast, species richness under $A$. adenophora canopies at all sites in the invaded ranges of China and India was much lower than in the open where there was no $A$. adenophora. In India, at Mussoorie site 1 species richness was $85 \%$ lower under $A$. adenophora $(7.5 \pm 0.3$ to $1.2 \pm 0.2$ species $/ \mathrm{m}^{2}$ [means $\left.\pm \mathrm{SE}\right] ; t$ test, $\mathrm{df}=1,38 ; t=$ 20.76; $P<0.0001)$, and at Mussoorie site 2 species richness was $69 \%$ lower $(20.7 \pm 0.7$ vs. $6.4 \pm 0.7$ species/ $\mathrm{m}^{2}$; df $=1,38 ; t=4.96 ; P<0.0001$; Fig. 1) under $A$. adenophora than where the invader was not present. In China, at Xujiaba A. adenophora was associated with $53 \%$ lower species richness than the surrounding vegetation $\left(11.8 \pm 0.6\right.$ vs. $5.6 \pm 0.6$ species $/ \mathrm{m}^{2} ; \mathrm{df}=1,38 ; t=13.11 ; P$ $<0.0001)$, and at Taizhong the richness was $64 \%$ lower under $A$. adenophora $\left(10.7 \pm 0.6\right.$ vs. $3.9 \pm 0.4$ species $/ \mathrm{m}^{2}$; $\mathrm{df}=1,38 ; t=11.40 ; P<0.0001$; Fig. 1). Although not statistically testable, the total number of species recorded at Moctezuma in Mexico was 45 species, with 34 species occurring under $A$. adenophora and 35 species occurring in the open - a mean difference in richness of $3 \%$. At this site 11 species were restricted to the open and 9 species were restricted to under A. adenophora canopies. At Querétaro there were 38 species, with 30 species found in the open and 26 species under A. adenophora - a mean difference in richness of $13 \%$. As at Moctezuma, 11 species were restricted to the open and 9 species were restricted to A. adenophora canopies. In China there were 111 species at Xujiba, with 98 of these species found in the open away from $A$. adenophora but only 54 species beneath $A$. adenophora - a mean difference in total species richness of $54 \%$. Fifty-five species were found only in vegetation away from $A$. adenophora canopies, and 9 species were found only under $A$. adenophora. There were 91 species in total at Taizhong in China and 79 species were found in the open; however, only 35 species were found under $A$. adenophora-a mean difference in richness of $56 \%$. Fifty-eight species were found only in vegetation away from $A$. adenophora canopies, and 6 species were found only under $A$. adenophora. In India there were 56 species found at the Mussoorie sites 1 and 2 combined, and 25 species were found in the open and 15 species under $A$. adenophora canopies, a mean difference of $40 \%$ in total species richness.

Biogeographical differences in total percent cover between Mexico and China (cover was not measured in India) were even more striking. The total cover of other species beneath $A$. adenophora canopies in Mexico was $71 \%$ higher than in the open $(44.8 \% \pm 2.6 \%$ vs. $76.8 \% \pm$ $6.2 \%$ [means $\pm \mathrm{SE}$ ]; $t$ test, df $=1,38 ; t=4.78 ; P<$ $0.001)$. But in China $A$. adenophora canopies were correlated with $75 \%$ less total cover at Xuijaba $(102.6 \% \pm 6.3 \%$ vs. $25.5 \% \pm 3.8 \%$; df $=1,38 ; t=$ 10.46; $P<0.001)$, and $79 \%$ less total cover at Taizhong $(83.3 \% \pm 6.9 \%$ vs. $17.2 \% \pm 3.6 \% ; \mathrm{df}=1,38 ; t=8.44 ; P$ $<0.001)$, suggesting strong inhibition. Note that adding cover of each species without relativizing as we did can lead to cover values greater than $100 \%$. For total cover values less than $100 \%$, the remaining nonvegetated cover
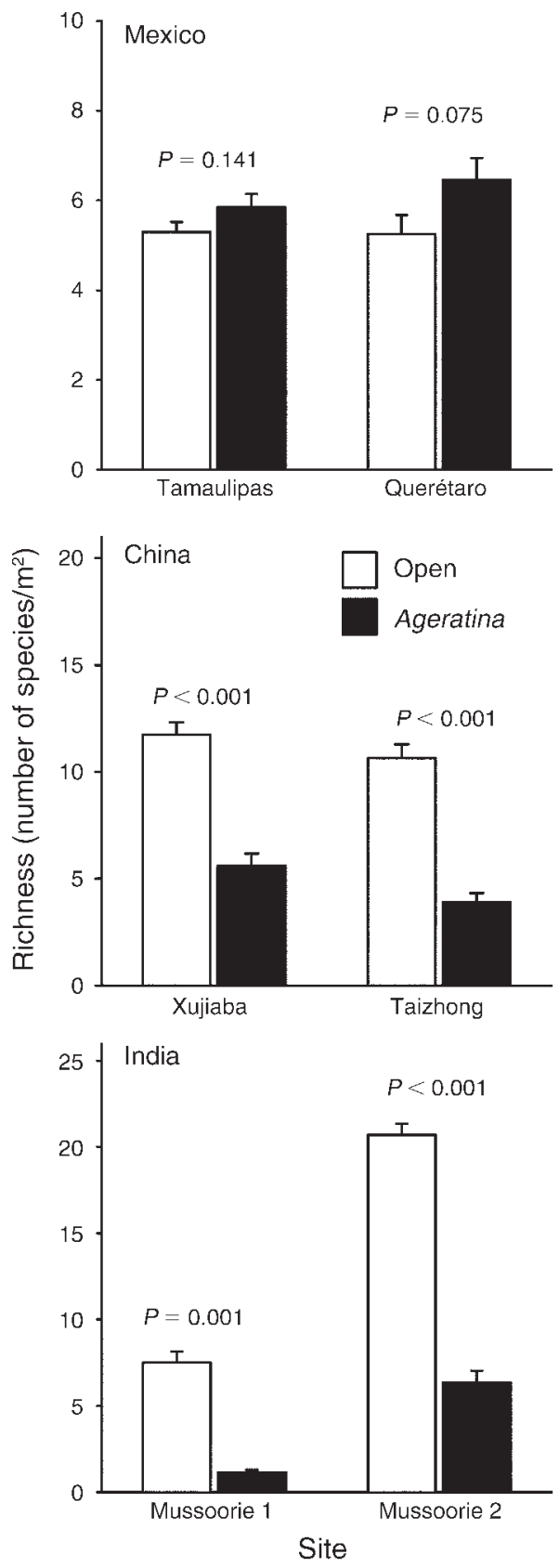

FIG. 1. Quadrat-based plant species richness under canopies of the subtropical invasive plant Ageratina adenophora and in the open at sites in Mexico, India, and China. Data are means $+\mathrm{SE} ; P$ values above paired bars are from independent $t$ tests.

was either bare ground or A. adenophora litter. The contribution of $A$. adenophora to total cover in its understories was less than $1 \%$ in both the native and nonnative ranges. Volatiles of A. adenophora leaf litter
inhibit the growth of other species

In petri dish experiments, Bambusa arundinacea seed germination was not inhibited $(t=0.180, P=0.858)$ after 


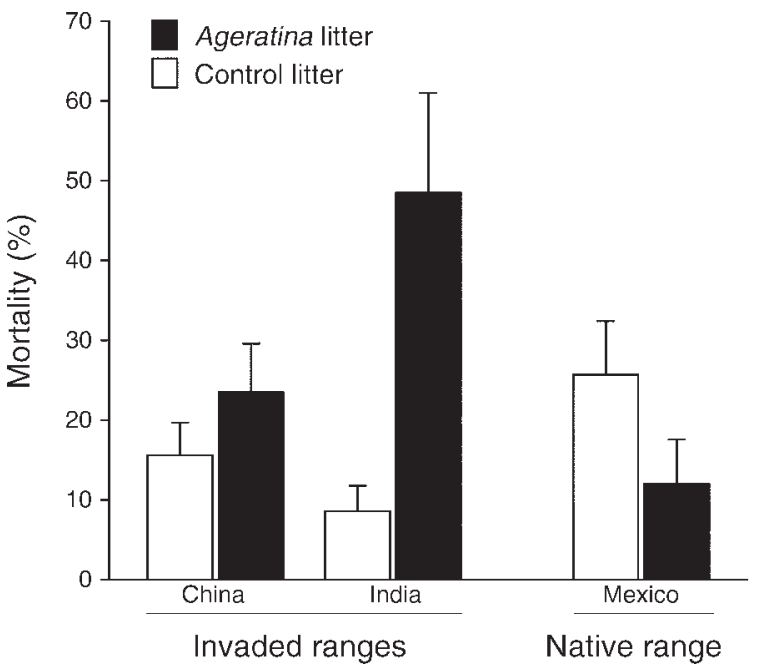

FIG. 2. Effects of volatiles from leaf litter of Ageratina adenophora, relative to control litter, on the mortality of species native to its invaded (China or India) ranges and species from its native (Mexico) range. Data are means + SE; for ANOVA results see Results: Volatile effects on species....

7 d by $A$. adenophora VOCs, but the germination of Bidens biternata seeds was highly suppressed (for final percentages; $t=6.767, P<0.0001$; Appendix A). The growth of the roots and shoots of both $B$. arundinacea $\left(t_{\mathrm{rt}}=15.232, P<0.0001 ; t_{\mathrm{sht}}=8.224, P<0.0001\right)$ and $B$. biternata $\left(t_{\mathrm{rt}}=9.329, P<0.0001 ; t_{\mathrm{sht}}=14.109, P<\right.$ $0.0001)$ was significantly suppressed by VOCs from $A$. adenophora leaf litter (Appendix A).

\section{Volatile effects on species from native and nonnative ranges}

The germination or growth of some individual species showed significant responses, either positive or negative, to VOCs emitted from $A$. adenophora litter, but exposure to VOCs had no significant overall effect on the germination or biomass of the combined pool of species from any of the three regions (data not shown). Of the seven species native to China that germinated at rates high enough to allow comparisons of mortality, Amaranthus tricolor $(41.3 \% \pm 11.4 \%$ [mean $\pm \mathrm{SE}$ ] mortality with $A$. adenophora litter VOCs vs. $14.8 \% \pm$ $2.6 \%$ in control) and Oxalis comiculata $(34.7 \% \pm 6.6 \%$ vs. $9.9 \% \pm 5.4 \%$ ) showed significant negative effects of VOCs as determined by pairwise $t$ tests using the mean mortality in a bin as replicates. For the remaining five Chinese species, Peperomia tetraphylla, Hemiphragma heterophyllum, Eupatorium chinense, Eupatorium japonicum, and Cucubalus baccifer, there were no significant effects of VOCs from litter. Of the seven species native to India with germination rates high enough for comparisons, Cassia fistula $(66.7 \% \pm 8.9 \%$ vs. $16.7 \%$ $\pm 8.8 \%)$, Bombax ceiba $(50.8 \% \pm 21.0 \%$ vs. $13.6 \% \pm$ $4.2 \%)$, and Dillenia indica (100\% vs. 0\%) showed significant effects of $A$. adenophora VOCs. VOCs had no effect on Lowsonia alba, Bambusa arundinacea, or
Withania sominifera. Of the five species native to Mexico with high enough germination rates, A. adenophora VOCs had no significant inhibitory effects on any species, and were correlated with significantly lower mortality for Desmodium graham (0\% vs. $38 \% \pm 11.5 \%$ in the control). There were no significant effects of $A$. adenophora VOCs on Viguieria spp., Poa spp., Panicum spp., and Senecio spp. In a two-way ANOVA with region as a fixed factor (combining species from both invaded regions), bin as a fixed factor, and with the mean for each species as a single replicate, the region $\times$ treatment interaction was significant $(F=5.201$; df $=1$, 37; $P=0.029$; Fig. 2), indicating that VOCs from $A$. adenophora litter had more inhibitory effects on species from the nonnative range of the invader than the native range.

\section{Concentrations of some volatiles differ between native and invasive ranges}

Many monoterpenes and sesquiterpenes were identified in the headspace analysis of $A$. adenophora leaf litter produced by plants raised from seeds collected from Mexico, China, and India (Appendices B and C). Plants from the native Mexican populations emitted significantly different concentrations of six different VOCs than either the invasive Chinese and Indian populations (Fig. 3; Appendices C and D). Plants from the Chinese and Indian populations showed very similar patterns in the VOCs that were emitted. Two monoterpenes, 2carene and $\alpha$-phellandrene, were at higher concentrations in the headspace of litter of plants from the invasive ranges; whereas the monoterpene $\beta$-pinene, and the three sesquiterpenes $(E)$ - $\beta$-caryophyllene, $(E)-\alpha$ bergamotene, and bicyclogermacrene, were at higher levels in the headspace of litter from plants of the native range. Direct extraction of leaf litter with organic solvent revealed the same terpenes in the same proportions as found in the headspace analyses, but recorded higher concentrations of the larger compounds (Appendix E).

\section{DisCusSION}

Ageratina adenophora, an invasive plant throughout the subtropics, was correlated with higher diversity and greater abundances of understory plants in its native range in Mexico. In contrast, in its nonnative ranges in China and India the presence of $A$. adenophora shrubs correlated with striking decreases in the richness and cover of native species. Although our limited number of field sites warrants caution in extrapolating to the whole of its invasive range, other studies of $A$. adenophora in Asia have shown negative effects on native species that are similar to those presented here. Based on regression relationships at the scale of $25-\mathrm{m}^{2}$ plots in southwest China, Lu and Ma (2005) found that native species richness averaged $>25$ species per plot when $A$. adenophora cover was near zero; however, when $A$. adenophora cover reached $\sim 60 \%$, native species richness 

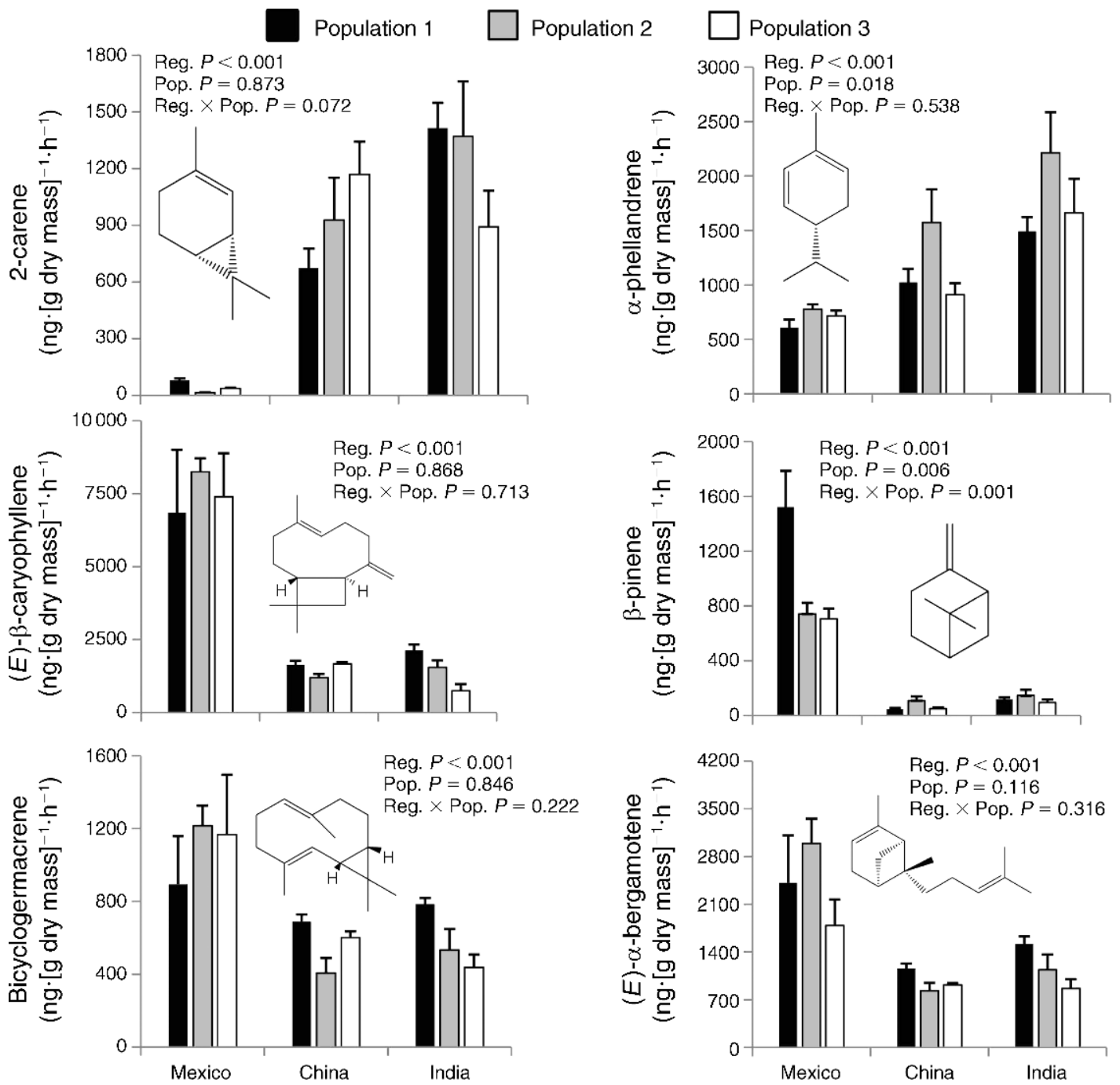

FIG. 3. Biogeographical differences in the emission of three monoterpenes [ $\beta$-pinene, 2 -carene, and $\alpha$-phellandrene] and three sesquiterpenes $[(E)$ - $\beta$-caryophyllene, $(E)$ - $\alpha$-bergamotene, and bicyclogermacrene]. Data are means $+\mathrm{SE}$; $P$ values are shown for two-way ANOVA.

declined to $<5$ species per plot. To our knowledge, no other study has quantitatively estimated the impact of an invasive plant species in the field in both its native and nonnative ranges, but a number of studies have clearly documented strong negative impacts of many invaders in their nonnative ranges (e.g., Hejda et al. 2009).

Many factors are likely to contribute to the invasive success of $A$. adenophora, but our findings suggest the potential of allelopathic VOCs as one of these. The allelopathic effects of VOCs from the litter of $A$. adenophora were stronger on species from the nonnative range than from the native range, a finding consistent with the novel-weapons hypothesis (NWH; Callaway and Ridenour 2004). Similarly, Ens et al. (2009a) examined VOCs produced by the roots of the invasive Chrysanthemoides monilifera in Australia and detected three volatile compounds that were found exclusively in C. monilifera roots and its rhizosphere. Higher production of terpenes was observed in C. monilifera roots, while Acacia longifera, a native species, produced more alkanes. Extracts from leaves and roots of $C$. monilifera suppressed more native Australian species than extracts from the dominant native Acacia (Ens et al. 2009b). That study, however, lacked biogeographical comparisons of VOCs in native and invaded ranges.

Here, we have shown that production of a volatile compound, to which plant species growing in invaded regions appear to be more susceptible, has the potential to contribute to the invasive success of $A$. adenophora. Of course, this is unlikely to fully explain $A$. adenophora invasion and does not rule out the importance of other mechanisms. For example, Niu et al. (2007) found that $A$. adenophora and soil biota in the invaded range 
interacted to establish positive feedbacks on $A$. adenophora, and that $A$. adenophora modified soil communities in ways that negatively impacted other species in the invasive range, suggesting the possibility that escape from soil pathogens may be important for invasion. In China, field surveys found an absence of specialist herbivores on $A$. adenophora (with the exception of a galling insect, Procecidochares utilis Stone, which was introduced into China in 1984), and that virtually no native generalists attack the plant (Feng et al. 2009). Procecidochares utilis was introduced as a biological control agent in India in 1963, but has been reported to cause only minor damage (Jayanth 2000). As for any exotic invasion, the relative importance of different mechanisms must be disentangled if we are to fully explain the process.

So far, the NWH has been explored in the context of regional novelty; i.e., the idea that some secondary metabolites might be unusually potent as allelopathic, antibiotic, or defense agents because of their novelty to organisms in nonnative ranges. However, it was not proposed that the invasive species would produce different concentrations of compounds in its nonnative ranges, as we have demonstrated here (but see Wikström et al. 2006, Ridenour et al. 2008). Our study suggests two potentially different interpretations of biochemical novelty in $A$. adenophora invasion, but our results do not favor one interpretation over the other. First, the effects in this experiment may be due to the adaptive naiveté of species from China and Mexico to chemicals produced by $A$. adenophora, no matter what the biogeographical source of the invader; the basic NWH. But we also found that the concentrations of some VOCs from leaf litter from populations of $A$. adenophora from China and India (grown under common conditions) were markedly different than those emitted from the leaf litter of $A$. adenophora grown from seed collected from Mexican plants, although many VOC concentrations were similar. Thus the biogeographical effects reported here might be due to the particular concentrations of VOCs produced by plants in invasive populations. However, there were no chemicals that were found only in either the native or nonnative ranges. The novelty of VOCs in nonnative ranges or novel concentrations of compounds are also conceptually consistent with ideas of the importance of evolving biochemical novelty in arms races between plants and their herbivore enemies (Ehrlich and Raven 1966).

The concentrations of 2-carene in the VOCs of leaf litter produced by $A$. adenophora plants from the invaded range (grown in a common garden) were three orders of magnitude higher than concentrations in VOCs from litter produced by $A$. adenophora plants from the native range (Fig. 3). $\alpha$-Phellandrene emission was about twice as high for populations from the invaded ranges as for populations from the native range. 2-Carene has been reported to have allelopathic effects (Vokou et al. 2003), and Kpoviessi et al. (2009) found that $\alpha$-phellandrene, a constituent of the essential oil of Justicia anselliana, had allelopathic effects. If these compounds contribute to the allelopathic effects of $A$. adenophora VOCs, high concentrations may have been selected for in the nonnative ranges (Callaway and Ridenour 2004, Wikström et al. 2006, Ridenour et al. 2008). However, $\beta$-pinene and ( $E$ )- $\beta$-caryophyllene were emitted in far higher amounts from litter from Mexican plants than from the litter of Indian or Chinese plants and these chemicals have also been reported to have important defense properties (Köllner et al. 2008). Perhaps these compounds are less active as allelopathic agents than 2-carene and $\boldsymbol{\alpha}$-phellandrene. Or, perhaps they are important in defense against specialist enemies that should be less abundant in the invaded ranges (Feng et al. 2009).

Our finding that all populations from India and China differed from all populations from Mexico raises the possibility that invasive populations of $A$. adenophora experience generally consistent selection to produce higher levels of some biologically effective compounds in their nonnative ranges. However, our populationscale sampling was far too small to exclude founder effects, an equally valid interpretation of differences in the amounts of specific VOCs produced in the native and nonnative ranges. Regardless, our results add to an emerging body of work emphasizing the biological importance of VOCs emitted from plants as allelopathic agents (Kessler and Baldwin 2002, Karban 2007). However, our results could be strengthened by comparisons of $A$. adenophora litter to litter from native plants in the invader's nonnative range in both pots and Petri dish experiments. Also, Inderjit et al. (2009) suggested the use of "silenced" plants to acquire conclusive evidence that the release of chemicals does matter in plant-plant interactions, but silencing a perennial plant for the production of more than one chemical may be a significant challenge and performing field experiments with silenced plants is yet another challenge. Perhaps the best way to demonstrate the role of VOCs produced by A. adenophora VOCs in the field will be through manipulative field studies that discriminate the effects of VOCs from those of competitors, pathogens, and herbivores.

Plants release chemicals into their immediate environments to forage for resources, defend themselves against consumers, communicate with each other, nurture mutualists, and to gain advantages over competitors (Inderjit et al. 2006, Karban 2007, Metlen et al. 2009, Pollock et al. 2009). Our spatially and regionally explicit results add to the body of knowledge about allelochemicals by suggesting the possibility of regional evolutionary trajectories (Thompson 2005) and have several interesting implications for community ecology. First, they add to a growing body of literature indicating that there is some degree of species specificity in the effects of plant-released secondary metabolites in plant-plant interactions (see Callaway 1998, Callaway et 
al. 2005). Second, if species-specific interactions among plants drive natural selection, then assemblages of plants, or communities, may be less individualistic than previously thought (see Lortie et al. 2004). Third, regional evolutionary trajectories suggest that novel competitive mechanisms used by invaders may disrupt coevolved interactions among long-associated native species. Finally, our results are consistent with the NWH, the idea that some invaders may succeed because they possess biologically active biochemicals to which species in the nonnative range have not adapted.

\section{ACKNOWLEDGMENTS}

Inderjit was funded by the Council of Scientific and Industrial Research. Funding to R. M. Callaway was provided by DoD SERDP, the National Science Foundation, the University of Montana Sponsored Research Office, and the Rocky Mountain Research Station. Funding to A. ValienteBanuet was provided by PAPIIT-DGAPA, UNAM project 224808-3. Support for C. Crocoll and J. Gershenzon was provided by the Max Planck Society. We thank C. R. Babu for his help in identifying plant species. We thank two anonymous referees for valuable comments.

H. Evans, C. Crocoll, D. Bajpai, and R. Kaur contributed equally to the manuscript.

\section{Literature Cited}

Barney, J. N., A. G. Hay, and L. A. Weston. 2005. Isolation and characterization of allelopathic volatiles from mugwort (Artemisia vulgaris). Journal of Chemical Ecology 31:247265.

Bartholomew, B. 1970. Bare zones between California shrub and grassland communities: the role of animals. Science 170: $1210-1212$.

Callaway, R. M. 1998. Are positive interactions species-specific? Oikos 82:202-207.

Callaway, R. M., and E. T. Aschehoug. 2000. Invasive plants versus their new and old neighbors: a mechanism for exotic invasion. Science 290:521-523.

Callaway, R. M., D. Cipollini, K. Barto, G. C. Thelen, S. G. Hallett, D. Prati, K. Stinson, and J. Klironomos. 2008. Novel weapons: invasive plant suppresses fungal mutualists in America but not in its native Europe. Ecology 89:1043-1055.

Callaway, R. M., and J. L. Maron. 2006. What have exotic plant invasions taught us over the past 20 years? Trends in Ecology and Evolution 21:369-374.

Callaway, R. M., and W. M. Ridenour. 2004. Novel weapons: a biochemically based hypothesis for invasive success and the evolution of increased competitive ability. Frontiers in Ecology and the Environment 2:436-443.

Callaway, R. M., W. M. Ridenour, T. Laboski, T. Weir, and J. M. Vivanco. 2005. Natural selection for resistance to the allelopathic effects of invasive plants. Journal of Ecology 93: 576-583.

Cappuccino, N., and J. T. Arnason. 2006. Novel chemistry of invasive exotic plants. Biology Letters 2:189-193.

Dakshini, K. M. M., and P. P. Singh. 1984. Taxonomy of Bidens section Psilocarpaea (Asteraceae-Heliantheae-Coreopsidinae) in India. Proceedings of Indian Academy of Sciences (Plant Science) 93:165-177.

Ehrlich, P. R., and P. H. Raven. 1966. Butterflies and plants: a study in coevolution. Evolution 18:586-608.

Ens, E. J., J. B. Bremner, K. French, and J. Korth. $2009 a$. Identification of volatile compounds released by roots of an invasive plant, bitou bush (Chrysanthemoides monilifera spp. rotundata), and their inhibition of native seedling growth. Biological Invasions 11:275-287.
Ens, E. J., K. French, and J. B. Bremner. 2009b. Evidence for allelopathy as a mechanism of community composition change by an invasive exotic shrub, Chrysanthemoides monilifera spp. rotundata. Plant and Soil 316:125-137.

Eom, S. H., H. S. Yang, and L. A. Weston. 2006. An evaluation of the allelopathic potential of selected perennial groundcovers: foliar volatiles of catmint (Nepeta $\times$ faassenii) inhibit seedling growth. Journal of Chemical Ecology 32:1835-1848.

Feng, Y. L., Y. Lei, R. Wang, R. M. Callaway, A. ValienteBanuet, Inderjit, Y.-P. Li, and Y.-L. Zheng. 2009. Evolutionary tradeoffs for nitrogen allocation to photosynthesis versus cell walls in an invasive plant. Proceedings of the National Academy of Sciences USA 106:1853-1856.

He, W. M., Y. Feng, W. Ridenour, G. C. Thelen, J. L. Pollock, A. Diaconu, and R. M. Callaway. 2009. Novel weapons and invasion: biogeographic differences in the competitive effects of Centaurea maculosa and its root exudate $( \pm)$-catechin. Oecologia 159:803-815.

Hejda, M., P. Pysek, and V. Jarosik. 2009. Impact of invasive plants on the species richness, diversity and composition of invaded communities. Journal of Ecology 97:393-403.

Inderjit, R. M. Callaway, and J. M. Vivanco. 2006. Plant biochemistry helps to understand invasion ecology. Trends in Plant Science 11:574-580.

Inderjit, C. C. von Dahl, and I. T. Baldwin. 2009. Use of silenced plants in allelopathy bioassays: a novel approach. Planta 229:569-575.

Jarchow, M. E., and B. J. Cook. 2009. Allelopathy as a mechanism for the invasion of Typha angustifolia. Plant Ecology 204:113-124.

Jayanth, K. P. 2000. Biological control of weeds in India. Pages 207-219 in R. K. Upadhyay, K. G. M. Mukerji, and B. P. Chamola, editors. Biocontrol potential and its exploitation in sustainable agriculture: crop diseases, weeds, and nematodes. Springer-Verlag, Berlin, Germany.

Jogesh, T., D. Carpenter, and N. Cappuccino. 2008. Herbivory on invasive exotic plants and their non-invasive relatives. Biological Invasions 10:797-804.

Karban, R. 2007. Experimental clipping of sagebrush inhibits seed germination of neighbours. Ecology Letters 10:791-797.

Karban, R., and K. Shiojiri. 2009. Self-recognition affects plant communication and defense. Ecology Letters 12:502-506.

Keane, R. M., and M. J. Crawley. 2002. Exotic plant invasions and the enemy release hypothesis. Trends in Ecology and Evolution 17:164-169.

Kessler, A., and I. T. Baldwin. 2002. Plant responses to insect herbivory: the emerging molecular analysis. Annual Review of Plant Biology 53:299-328.

Köllner, T. G., M. Held, C. Lenk, I. Hiltpold, T. C. J. Turlings, J. Gershenzon, and J. Degenhardt. 2008. A maize (E)- $\beta$ caryophyllene synthase implicated in indirect defense responses against herbivores is not expressed in most American maize varieties. Plant Cell 20:482-494.

Kpoviessi, D. S. S., J. D. Gbenou, F. A. Gbaguidi, L. Ahoussi, G. C. Accrombessi, M. Moudachirou, and J. QuetinLeclercq. 2009. Justicia anselliana (Nees) T. Anders essential oils compounds and allelopathic effects on cowpea Vigna unguiculata (L.) Walp plant. Journal of Essential Oil Research 21:83-88.

Levine, J. M., M. Vilà, C. M. D'Antonio, J. S. Dukes, K. Grigulis, and S. Lavorel. 2003. Mechanisms underlying the impacts of exotic plant invasions. Proceedings of the Royal Society of London B 270:775-781.

Lortie, C. J., R. W. Brooker, P. Choler, Z. Kikvidze, R. Michalet, F. I. Pugnaire, and R. M. Callaway. 2004. Rethinking plant community theory. Oikos 107:433-438.

Lu, Z., and K. Ma. 2005. Scale dependent relationships between native plant diversity and the invasion of Eupatorium adenophorum in southwest China. Weed Science 53:600-604. 
Mangla, S., Inderjit, and R. M. Callaway. 2008. Exotic invasive plant accumulates native soil pathogens which inhibit native plants. Journal of Ecology 96:58-67.

Maron, J. L., and M. M. Marler. 2008. Field-based competitive impacts between invaders and natives at varying resource supply. Journal of Ecology 96:1187-1197.

Metlen, K. L., E. T. Aschehoug, and R. M. Callaway. 2009. Plant behavioural ecology: dynamic plasticity in secondary metabolites. Plant Cell and Environment 32:641-653.

Muller, C. H. 1965. Inhibitory terpenes volatized from Salvia shrubs. Bulletin of the Torrey Botanical Club 92:38-45.

Muller, C. H., W. H. Muller, and B. L. Haines. 1964. Volatile growth inhibitors produced by aromatic shrubs. Science 143: 471-473.

Munshaw, M. G., and C. J. Lortie. 2010. Back to the basics: using density series to test regulation versus limitation for invasive plants. Plant Ecology. [doi: 10.1007/s11258-010-9764-3]

Niu, H., L. Wan-xue, W. Fang-hao, and B. Liu. 2007. An invasive aster (Ageratina adenophora) invades and dominates forest understories in China: altered soil microbial communities facilitate the invader and inhibit natives. Plant and Soil 294:73-85.

Palá-Paúl, J., M. J. Pérez-Alonso, A. Velasco-Negueruela, and J. Sanz. 2002. Analysis by gas chromatography-mass spectrometry of the volatile components of Ageratina adenophora Spreng., growing in the Canary Islands. Journal of Chromatography 947:327-331.

Pollock, J. L., R. M. Callaway, G. C. Thelen, and W. E. Holben. 2009. Catechin-metal interactions as a mechanism for conditional allelopathy by the invasive plant, Centaurea maculosa. Journal of Ecology 97:1234-1242.

Ridenour, W. M., J. M. Vivanco, Y. Feng, J. Horiuchi, and R. M. Callaway. 2008. No evidence for tradeoffs: Centaurea plants from America are better competitors and defenders than plants from the native range. Ecological Monographs 78:369-386.

Song, Q. S., Y. Fu, J. W. Tang, Z. L. Feng, and C. R. Yang. 2000. Allelopathic potential of Eupatorium adenophorum. Acta Phytoecology Sinica 24:362-365.

Thompson, J. N. 2005. The geographic mosaic of coevolution. University of Chicago Press, Chicago, Illinois, USA.

Vilà, M., and J. Weiner. 2004. Are invasive plant species better competitors than native plant species? Evidence from pairwise experiments. Oikos 105:229-238.

Vokou, D., P. Douvli, G. J. Blionis, and J. M. Halley. 2003. Effects of monoterpenoids, acting alone or in pairs, on seed germination and subsequent seedling growth. Journal of Chemical Ecology 29:2281-2301.

Wang, R., and Y. Wang. 2006. Invasion dynamics and potential spread of the invasive alien plant species Ageratina adenophora (Asteraceae) in China. Diversity and Distribution 12:397-408.

Wikström, S. A., M. B. Steinarsdóttir, L. Kautsky, and H. Pavia. 2006. Increased chemical resistance explains low herbivore colonization of introduced seaweed. Oecologia 148:593-601.

Zhang, K.-M., L. Shi, C.-D. Jiang, and Z.-Y. Li. 2008. Inhibition of Ageratina adenophora on spore germination and gametophyte development of Macrothelypteris torresiana. Journal of Integrative Plant Biology 50:559-564.

Zhu, L., O. J. Sun, W. Sang, Z. Li, and K. Ma. 2007. Predicting the spatial distribution of an invasive plant species (Eupatorium adenophora) in China. Landscape Ecology 22:11431154.

\section{APPENDIX A}

Figures summarizing seedling length and germination data of Bidens biternata and Bambusa arundinacea grown in the presence or absence of Ageratina adenophora leaf litter (Ecological Archives E092-028-A1).

\section{APPENDIX B}

A figure presenting volatiles collected from headspace of 200-mg air-dried leaf material of three different origins (Ecological Archives E092-028-A2).

\section{APPENDIX C}

A table presenting the volatile compounds collected from headspace of leaf litter of Ageratina adenophora of different regional origins (Ecological Archives E092-028-A3).

\section{APPENDIX D}

Tables for two-way ANOVAs for the effect of region (Mexico, China, or India) and population on the concentration of six selected terpenes from Ageratina adenophora (Ecological Archives E092-028-A4).

\section{APPENDIX E}

A figure comparing volatiles collected through solvent extraction or from headspace of 200-mg air-dried leaf material of three different origins (Ecological Archives E092-028-A5). 